Article

\title{
Violent Jihad and Beheadings in the Land of Al Fatoni Darussalam
}

\author{
Virginie Andre
}

Alfred Deakin Institute for Citizenship and Globalisation, Deakin University, 221 Burwood Highway, VIC 3125 Burwood, Australia; E-Mail: virginie.andre@deakin.edu.au

Academic Editor: John L. Esposito

Received: 11 August 2015 / Accepted: 24 September 2015 / Published: 14 October 2015

\begin{abstract}
The early 2000s has seen a revival of the Patani resistance manifesting in a violent jihad and new forms of extreme violence never witnessed before in the century-long Southern Thailand conflict. Transported by neojihadism, this new energised generation of fighters is injecting new meaning to their struggle, re-identifying friends and foes, spreading terror in hearts and minds to control mental and physical spaces through the slashing of the body, all in the hope of establishing Al Fatoni Darussalam. This article examines the reflexive repositioning of the Patani struggle through the process of transference of neojihadism and its transformation into a glocalised violent jihad.
\end{abstract}

Keywords: Patani; globalization; hybridization; extremism; neojihadism; violence; religion; war; identity; beheading

\section{Introduction}

The long-standing Muslim separatist conflict of Southern Thailand is a one of those forgotten wars that rarely attracts any attention from the media or the international community. This can be partially explained by the discrete nature of the Muslim extremist separatist movement and its domestic focus. Unlike other Islamic extremist movements in the region, it has not pledged any allegiance to Al Qaeda. Yet, the revival of the resistance in the early 2000 under the banner of a localised neojihadism transported by a new energised generation of fighters is particularly informative of the process of neojihadism transference in the region, and how it could potentially serve as a blueprint to other Muslim minority conflicts in the Southeast Asian region, and other parts of the world. 
The Patani ${ }^{1}$ movement of resistance finds its roots in the period that follows the signature of the Anglo-Siamese Treaty (1909) by which the Sultanate of Patani was officially annexed to the Kingdom of Siam, now known as Thailand, formalising the subjugation of a distinct people to a foreign entity [1-3]. Following the signature of the Treaty, the Siamese government was confronted by different waves of organised Muslim political resistance, ranging from civic activism to armed resistance. More recently (late 2001 and increasing in 2004), after an almost 20 year period of apparent peace, the Patani struggle has taken on a new turn with the resurgence of violence expanding against civilians (including the beheadings of monks and attacks on Buddhist temples), reflecting a level of brutality never before witnessed in the century long conflict. The brutal killing of both Buddhists and Muslims, arson attacks against schools and systematic violence against teachers, coupled with the emergence of an exclusivist Islamic discourse and the refusal of all parties to engage in meaningful peace negotiations suggest the conflict is passing through a transformational stage and that over time it could depart from traditional patterns of violence characteristic of ethno-nationalist struggles in Southeast Asia in the post-colonial period and evolve into a more broad-based violent campaign with a greater blurring of the distinction between civilian and combatant. Today, the region is home to 1.5 million Melayu ${ }^{2}$ Muslims who live in the three southernmost border provinces of Pattani, Yala and Narathiwat of Buddhist Thailand.

The failure in late 2001 of the Thai state to anticipate the resurgence of violence in the three southern provinces, and its parallel failure to develop a sustainable peace process, stems from two principle sources; its poor understanding of Southern Muslims as a distinctive people with their own sense of a separate identity and culture, and secondly a failure to grasp the capacity of external forces to re-energise and rejuvenate secessionist sentiment that is based on these distinctive patterns of culture and identity. To this end, the growing sense of global Islamic consciousness has given new meaning to the struggle that many Thai Muslims believe confronts them. This sense of supraterritoriality is increasingly encroaching into the political discourse of the new insurgent groups as they strive to differentiate themselves and their communities from wider Thai society.

In the 1970s secessionists in Southern Thailand described the Thai state as "colonialist" constituted by "Siamese fascist officials" who had "illegally colonised Patani" [4-6]. The flavour of this discourse shows the importance of historical context in shaping the way resistance movements interpret their own struggles. In the case of the resistance groups in Southern Thailand, it reflects the influence of the wider international anti-colonial movement and its embrace of nationalism and socialism. Translating these concepts into a political agenda was complicated by the centrality of Islam as an identity marker in defining the grievances of the Patani Muslims. Islam was the reason they were considered marginal by wider Buddhist society and hence it was Islam that become a core identity marker and the fulcrum upon which the resistance movement grew [6]. Merging the predominately secular themes of

1 Please note the author's usage of different spelling of "Patani" when referring to the people of Patani or the former Sultanate of Patani, which derives from the Malay language and of "Pattani" when relating to the Thai administrative territorial division.

2 Melayu in English means Malay. In Thailand, the people of the former Patani Sultanate are referred to as Melayu in opposition to the more general labelling of Thai Muslim. Hence, here the term Melayu is used when referring to the Patani Malay Muslims or the Patani Malay community. 
anti-colonialism with Islam was complex, and as a result for much of its existence the insurgency failed to define clearly an ideology beyond the general maxim of "liberating the homeland" to create the Republic of Patani. By the onset of the twenty-first century the situation had changed and although the goal remained the same for many Thai Muslims it was based on firmer ontological ground. By defining itself in Islamist terms, the separatist movement managed to distance itself from the secular concepts that defined the Thai state ("nationalism") and which precluded support for its struggle from other states ("sovereignty"). The objective now is the creation of Al Fatoni Darussalam (Islamic Land of Patani) by "purging all Siamese infidels out of our territory to purify our religion and culture" [7]. In short, the shift in terminology indicates an ideological shift in the way the insurgents frame the conflict but also, more importantly, in their identification of the "enemy" [6]. The "liberation of the Republic" has now evolved into a "struggle to liberate an Islamic Land" [6]. From being a "colonialist" and "fascist" state, the Thai state has assumed the status of "infidel" [6]. The insurgents' embrace of Islamism as the organising principle of their resistance is progressively transforming the conflict into what Juergensmeyer has called a "Cosmic War" [8].

The reflexive repositioning of the struggle by a new generation of militants within a larger transnational Islamic context has not only raised their own international profile in global Islamist circles but it has helped revitalize the struggle for a new and more internationally savvy generation of Patani Muslims, allowing them to feel as though they are part of a larger global movement. The intertwining of the global and the local is driving political violence to unprecedented extremism in Southern Thailand. From a traditional ethno-nationalist struggle the insurgency in Southern Thailand has now morphed into a glocalised jihad that is inspired by global forces but which is focused on local injustices [5,6].

\section{Patani's Neojihadist Sphere}

The Patani insurgency's adoption of Islamic radicalism and its extreme manifestation has progressively moved the struggle away from ethno-nationalism and classical jihadism propelling them into the neojihadist sphere of influence. Neojihadism distinguishes itself from jihadism in that it advocates terrorism to effect political change, draws on global processes and operates within the context of a global rather than local consciousness ([9], pp. 15-16). Because jihadism was mainly concerned with the establishment of sharia within Muslim-majority states where Muslims were being oppressed, it involved combat with state agents, not civilians or non-combatants ([9], p. 16). Furthermore, neojihadism uses selective literal interpretations of the Qur'an and the traditions of the Prophet Muhammad to sanction terrorist violence ([9], p. 16); a characteristic shared by the Patani insurgency. Neojihadism in southern Thailand is in fact a localised form of neojihadism, which shares some elements with its global form but not all, as its goal remains the restoration of its sacred ancestral homeland (not the formation a pan-Islamic state) which has brought some neojihadists to question the nature of the southern struggle. In Patani localised neojihadism new global forms are hybridized with old local forms of the struggle, tactics are knocked off and localised, all giving birth to a glocalised jihad and new forms of violence in the view of establishing Al Fatoni Darussalam. At the same time, because of the similarities it shares with the global form of neojihadism, it places the insurgency within 
the content of global Islamic struggle resulting in an increased interest within the global neojihadist community.

By injecting new meaning to their struggle through the localisation of the locus of neojihadism, the Patani insurgents have transformed their struggle into a religious obligation for all Melayu Muslims and created a motivational appeal for its core group, the Patani youth; an appeal that nationalism alone could no longer generate in a new globalised era [6,7]. Globality has facilitated the ideological transference processes by which the insurgency has localised elements of neojihadism within its renewed ideological discourse. In this new global context, Islam acts as globalising agent, shaping, on one hand, the inward and outward worldview of the movement while on the other hand providing it with a vision from which models can be derived. Moreover, Islam also acts as a filtering framework in the hybridisation of this global form or elements of global forms. Neojihadism is such a model from which the separatist terrorist insurgency has drawn ideological and tactical elements. What makes neojihadist transference possible and its subsequent hybridisation into Patani instrumentalisation of Islam successful is the affinities they share, i.e., a common Islamic and Muslim culture.

The tenets of Patani radical Islam revolve around the central themes of defensive jihad, kafir (infidel), munafiq (traitor), Al Fatoni Darussalam and shahid (martyr). The insurgency is leading a defensive jihad, which they believe finds its justification in the forced annexation of the Sultanate, the oppression endured by its people and the enslavement of Islam under Siamese rule. Additionally, emphasis is made on the transcending irreversible and binding nature of the conversion of the land to Islam (dar al-Islam) which must be dutifully restored (dar al-harb); an emphasis which differs from the Melayu nationalist rhetoric of an earlier generation of insurgents.

Within this defensive jihad, fellow Muslims who collaborate with the state or criticise publicly the insurgency are identified as munafiq who will be punished for their treachery against "their nation, religion and selves". Fellow Muslims, however, are forewarned and hypocrites are given the opportunity to repent. An emphasis is made on the religio-ethnicity proscribing them from joining or allying with other groups than theirs, especially the kafir Siam and failure to do is punishable by death resulting in the killing of innocent Muslim civilians. This is another element closely related to neojihadist movements where the takfiri practice by which a Muslim is declared an unbeliever justifies the shedding of Muslim blood. The munafiq and the kafir are declared enemies of Islam and the movement.

According to the Al Qur'an (4:140; 9:68), "God will gather all the hypocrites and disbelievers together into Hell" and "promises the Fire of Hell as a permanent home for the hypocrites, both men and women, and the disbelievers: this is enough for them. God rejects them and a lasting punishment awaits". In these verses, both the munafiq and the kafir, indistinctly are declared enemies of the faith and share a common destiny that is of rejection and punishment by death. The same logic of association is found within the insurgency's process of identification of friends and enemies where Muslim collaborators (or munafiqs) are associated with the enemy (kafir Siam). The insurgents claim:

"The enemy is only the kafir siam, [but] whoever follows them or offer their services to them, we will consider these individuals to be the same kind as them [kafir]. If you or your relatives offer their services [to the kafir], we will not guarantee your own safety"; "Do not believe the kafir siam under any circumstances because the kafir people are Shaytan [satan] 
in human's clothing. Both kafir and Shaytan are the enemies of Allah. The enemies of Allah are our enemies and anyone who follows the way of Shaytan and the kafir will be called 'munafiq', is it not? All, shaytan, kafirs and munafiqs as a rule live in everlasting hell". 3

This religious dichotomy of friends and enemies is particularly significant as it allows a better understanding of the logic and mechanisms that legitimise the expansion of insurgent violence to the civilian Buddhist and Muslim communities, another trait of neojihadism. Furthermore, it appears that Al Fatoni Darussalam cannot be established as long as it remains under kafir rule. Its establishment requires a liberation and a freedom from any form of Thai encroachment calling for a tabula rasa. However, the insurgency has yet to expand on its definition of an Islamic state that would transcend their utopian description of an Islamic state where justice and righteousness would rule under the love of God until Judgement Day.

The southern separatist insurgency's instrumentalisation of Islam should not be reduced to a fashionable trend characteristic of post 9/11 Islamic resistance movements from which it has drawn its rhetorical inspiration. Rather, it should be envisaged as a necessity to the movement's survival. By localising the struggle in the locus of neojihadism, not only has the separatist insurgency successfully injected new meaning to its fight but also is successfully elevating the conflict to unprecedented levels of legitimacy and authority, i.e., of a Holy war.

By leading a defensive jihad that aims to restore the Islamic Patani state by waging a vengeful violent war against the Infidel Siamese oppressor, the southern separatist insurgency appears to fall within the sphere of influence of "neojihadism". Neojihadism is an ideology that can be adopted and localised within the context of the struggle in Southern Thailand to achieve its own end. In truth, although the nature and the ideology may have changed, the struggle's ultimate goal remains the same; it is after all about the creation of an independent nation-state, surely Islamic in essence but of which the contours remain to be defined. In fact, the insurgency's re-interpretation of the scriptures serves the sole purpose of establishing this independent nation-state.

By re-defining the Thai state as kufir, the insurgents have proclaimed violent jihad not only against the Thai state but also on its ontological essence, its "Thai-ness", including chart (nation), satsana (religion), and phramahakasat (the monarchy). Through this insurgent process of re-identification of the enemy, the Thai Buddhist is dehumanised, demonised and eventually killed; the kafir harbi siam becomes the "cosmic foe" or "shaytan in human's clothing". This process of satanization of the enemy, explains Juergensmeyer ([8], p. 175), is part of the construction of an image of cosmic war, which becomes particularly operational when people, like the Patani Melayu Muslims, feel oppressed or have suffered injuries at the hands of the dominant.

The new generation of insurgent stated goals to purify their religion and culture requires a purge of "Siamese infidels" and is the raison d'être behind the movement's recent expansion of its targets to include civilians, including children, women and elders. Now that Thailand and the Thai Buddhists have become the "infidel enemy", transforming everything that incarnates "Thainess" into a worthless "Other", stripped of any personhood, acts of terrorism against the "enemy" have become acceptable in the eyes of the insurgents, and the use of beheading in Southern Thailand is an outgrowth of this re-identification process.

\footnotetext{
3 Separatist leaflet, the Fighters of the state of Fatoni Darussalam, undated.
} 
In its re-interpretation of the scriptures and mobilisation of religious symbolism, the insurgency has paid particular attention to religious concepts instrumental in the legitimisation and waging of a jihad and its enactive violent form.

\section{The Sacralisation of a Conflict and Its Praxis}

By casting the Patani struggle within the locus of neojihadism under the impulse of globalisation, it has transformed the movement's ideological nature and scope resulting in new forms and patterns of violence characteristic of new wars, significantly transforming battlefield violence and its effect on local communities. It has given birth to a new praxis with distinct features symptomatic of new wars, and departs significantly from the classical models of revolutionary struggle. The insurgency's justification and strategy for the Patani armed struggle in its early days spoke the language of Melayu nationalism and drew less on Islamic traditions than on models of revolutionary struggle or "people's war" developed by the Vietnamese and Algerians in their struggle against colonialism. In fact, anti-colonial struggles springing across the Southeast Asian region in the post World War II heavily influenced the movement in its claim for a separate and independent state while the communist insurrections influenced the insurgency in its strategy for armed struggle.

Where an older generation of insurgents - communists and separatists - relied on the people's support for their survival, the new generation seeks political mobilisation through terror and elimination of the kafir siam and the munafiq, giving birth to a hybridized notion of people's war. The new generation of insurgents draws more heavily on the Islamic traditions of war and the narratives of neojihadism in its justification and strategy for its armed struggle giving birth to a hybridized insurrectional model where political violence predominantly affects civilians. The re-definition of the enemy along religious and ethnic fault lines has translated into an expansion of violence to civilian citizens and an increase in victimisation of Thai Buddhists. In this new cosmological ideology, civilian citizens are no longer protected by conventional rules of war, creating and blurring at the same time the line between civilians and combatants, and a previous notion of a people's war which in the past depended on the people's willing support and not fear. Today, this new warfare features a tendency to avoid battle and to direct most violence against civilians, which is evidenced by the dramatic increase in the ratio of civilian to military casualty. Government and village officials, politicians, civil and municipality servants, teachers, students, doctors and nurses, businessmen, merchants, religious leaders and villagers have now come under insurgent fire [10].

To sustain a climate of fear, the use of indiscriminate means of violence, mainly of bombs or IEDs in open spaces, has drastically increased. Roadside bombs, motorcycle and car bombs exploding in public spaces have become part of the daily violence landscape. The insurgency increasingly uses extreme violence, nonexistent in an earlier era, against civilians with the aim to force people "to take sides" in its "people's war", thus, widening communal tensions between Buddhist and Muslim communities and forcing each community to entrench itself behind the security of their respective identities. The daily violence and its more extreme strand have eroded Southern Thailand's social fabric by generating fear, mistrust and division among Thai Buddhists and Melayu Muslims.

The new praxis of Patani terrorism derives both from the transformation of the struggle into a cosmic war and the centrality of a religious identity which are shaped by a mixture of global and local 
forces further transforming the movement. As a result of the convergence of these forces, Patani separatist terrorism is taking on a dangerous and extreme trajectory.

The use of extreme violence is a distinctive feature of this new type of warfare, which takes new meaning within the Patani struggle and the extent to which these practices, in particular beheadings, are manifestations of the glocalisation of neojihadism in the region.

\section{Extreme Violence and Transference of Neojihadism}

In its localisation of neojihadism, the insurgency not only has expanded its violence to civilians who now embody the enemy kafir or munafiq, but also adopted extreme forms of violence that follow ethnic fault-lines - a pattern departing significantly from a previous campaign of violence. Particular forms of extreme violence have been adopted as fear strategies in order to exert and preserve political control over the population. The human body has, in fact, become a political symbol, where the barbaric desecration of flesh and bones cuts across the interfaith and intercultural relationships between the communities.

In Patani, the extreme violence takes on the forms of machete hacking, torching of victims (sometimes alive), beheadings and isolated cases of crucifixion and genital mutilation while violence is characterised by drive by shootings, roadside bombs, motorcycle and car bombs. Between 2004 and 2009, over one hundred fifty cases of extreme violence have been recorded: fifty-nine machete hackings, forty-seven killing and burning incidents, fifty-two decapitations, one crucifixion and two cases of genital mutilation [10].

The broadcasting of insurgent atrocities over the Internet on platforms such as YouTube increases the spectacle effect of extreme violence by ensuring it reaches wider audiences [11,12]. Additionally, it enables the lifting of any notion of temporality on these exactions, as the act is continuously played and replayed and the body of the victims repeatedly desecrated. It becomes an indefinite political spectacle of human body desecration.

A significant extreme form of violence, which further indicates a shift from a previous campaign of violence, is the Patani insurgents' use of beheadings. As noted above, a total of fifty-two cases of decapitations were recorded. The practice of beheading is of particular interest, as unlike other types of extreme violence, it results both from the ideological transformation of the movement, and, the "knock off" $^{4}$ ([13], p. 184) and glocalisation of a neojihadist practice. The adoption of the neojihadist beheading strategy by Patani insurgents is particularly useful in understanding the mechanism of transference and glocalisation of neojihadist ideas and tactics at play within the region, which in turn further informs us on the transformative process of the insurgency.

The contemporary use of beheadings in the Patani insurgent terror campaign has prompted many local and international observers to link the practice to the Middle Eastern trend. Certainly, the increasing access to the Internet, the circulation in southern Thailand of video recordings showing beheadings from Iraq or Chechnya [5] and the recovery of such material by security personnel in 2007 suggest that the southern insurgency has not only knocked off its contemporary theological-ideological inspiration from neojihadism but also its extreme violent strand.

4 According to Lentini, knock-off terrorism "implies that potential terrorists have observed a model of conducting political violence that has worked and they attempt to knock off the procedure for their own purposes" [8]. 
These types of recordings allow the insurgency to enter the discourse of neojihadism and to draw from this rhetoric to imbue their own struggle with a renewed contemporary significance, but also more specifically it enables them to penetrate the violent praxis of this particular sphere of influence. Although the insurgent groups are not the primary target audience of these videos, the relative "success" of the methods utilised in the conduct of political violence shown in these have become a source of symbolic and technical know-how easily adaptable and readily available for acquisition by groups such as the Patani insurgency. However, as Lisa Campbell ([14], p. 609) notes, while "global access of video-taped beheadings may be inspiring more worldwide beheadings, (...) in many locations beheadings are not new and have historical cultural precedent".

Henceforth, beheadings in southern Thailand should not be perceived as copycat. Here, the concept of "knock off terrorism" [8] is particularly useful to understand the underlying rationale of the Patani insurgency for adopting the practice of beheading in their struggle. More than what is perceived by Thai authorities to be a mere reproduction or copycat of the Iraqi beheadings, it can be argued that Patani insurgents recently adopted decapitation as a strategy for its (believed) propensity to generate political change by instilling fear; a characteristic intrinsic to knock off terrorism ([8], p. 184). Patani beheadings can be considered a form of terrorism innovation in the sense that the movement has adopted a tactic, which is new to the organisation but "has already been used by other organisations in the past" [15].

Although the appearance of beheadings in Southern Thailand may have found its inspiration from the contemporary Middle Eastern trend, particularly from the Iraqi insurgency, the practice of beheading is not new to Thailand. Significant differences in practices emerge suggesting that the southern trend departs from its Middle Eastern counterpart, unveiling a locally rooted tradition and the significance of cultural memory in the perpetuation of extreme violence.

Former insurgents have denounced these brutalities, in particular the use of beheadings, as it is probably the form of extreme violence that strikes people's imagination the most (which in turn provides further information on the spectacle value of such practice and the emotional fear it inspires).

The bodies of kafirs and munafiqs have become a "theatre for social performances and productions" [16]. The body is in fact used "to establish the parameters of this otherness, taking the body apart, so to speak, to divine the enemy within" [16]. These extreme forms of violence aim to show that the perpetrator does not "recognize the identity of the others as legitimate" and implies it a negative ascription or labelling ([17], p. 419).

The dismemberment and burning of human bodies, mainly of Thai Buddhists, reflects an attitude, which perceives the identity of the enemy as illegitimate, undeserving of any respect. And when such violence is directed towards Melayu Muslims, the insurgents reflect the labelling of all these individuals as the enemy, for not taking sides, or for not fighting alongside the insurgents. The dismemberment, burning or mutilation of the body, therefore, can be seen as a symbolic gesture at the rest of the community, the communities of the area that witness the aftermath or hear of the head or corpse found down the street. These acts indicate cultural design and violent predictability ([16], p. 235).

These exactions are not only about destruction but also reflect "bloodshed executed in a deliberately intense and vivid way", which seeks to "maximize the savage nature of their violence" and "purposely to elicit anger" ([8], p. 121). These acts of terrorism are "deliberately exaggerated violence" ([8], p. 122) as it is about creating a spectacle of violence, a symbolic and theatrical act. Juergensmeyer ([8], p. 125) 
discusses this in detail, with specific attention to religious terrorism more generally, which he states is heavily symbolic because incidents are "intended to illustrate or refer to something beyond their immediate target".

Incidents take place in public places usually when villagers are often on their way to work, school or home. By executing such violent acts on the streets or in places such as rubber plantation sites, the insurgents are attempting to control central spaces, "by damaging, terrorizing and assaulting them" ([8], p. 134).

These acts of exaggerated cruelty seek not only to kill the opponent, but to humiliate, to undermine and crucially, to generate immense fear among the population. The body of the victim is portrayed and perceived as a symbol in the theatre of this violence. The attacks generate major rifts and anger among the Thai Buddhist community - precisely the intention of the act itself. The stabbing or slashing of a Buddhist monk does not only cause harm or leave wounds on his body, but also cuts across the interfaith and intercultural relationships between the people. Where a Muslim man is attacked on his way home from a mosque, it can be interpreted as a criticism for not taking sides and joining the fight. This violence has intimidated the vast bulk of "the Muslim population into acquiescence or at least into silence" ([18], p. 92). Attacking individuals who are in places of worship, or attacking weak targets such as the elderly, are very much considered as violations of taboo and social norms [19] — generating the hysteria and rifts the insurgency strives for.

The beheadings, attacks with machetes, the shooting and burning of Buddhist and Muslim victims forces everyone to engage with the conflict, take over public spaces and make them threatening or dangerous, and also, crucially, use the human body as a means to challenge the sovereignty of the Thai state.

While the significance and purpose of the use of extreme violence by the Patani insurgency lies in the spectacle and political value it carries, which was enabled by the instrumentalisation of an Islamic identity as a motivational factor and ideological rhetoric, it does not allow to explain why particular forms of extreme of violence are chosen over others. In this instance, the examination of the Patani beheading praxis helps unfolding the processes at play in adopting particular forms of violence.

In their transformation from an ethno-nationalist conflict into a cosmic war, the Patani insurgents had to draw from several sources to revive and imbue their own struggle with a renewed contemporary significance and legitimacy. In this respect, the decision and justification to use beheadings by southern insurgents in their fight to liberate the homeland can be regarded as an outgrowth of their transformative process into a cosmic war.

In Southern Thailand, history and their narratives are instrumental in the Muslim community's formation of collective memory and identity. As such, the insurgent movement draws its inspiration from these different competing historical narratives-Thai and Muslim - in the articulation of its ideology and its extreme violent manifestation, such as the use of beheading. On one hand, the historical continuity of decapitation in Thailand constitutes for the insurgents a source into which they can tap, which in turn enables them to signify their resistance to the state but also to make a blatant declaration of power by exercising a practice that was originally the state's exclusive prerogative.

On the other hand, Muslim history and scriptures provide the insurgents with an almost inexhaustible source from which they can draw upon without any consideration for the context in which these historical precedents took place. In fact, the fluidity of Islamic concepts and their 
interpretations is an intrinsic characteristic of Islam. For instance, as British Muslim academic Mona Siddiqi points out, "fiqh, [Islamic jurisprudence] though a pious endeavour was still a human attempt to elaborate what might be God's will and though it may have outlined ethical norms using the various tools at hand including the scripture, it never ceased to be a fluid expression of the Divine will". Because the Qur'an is open to interpretation, this means that Muslim communities can either use or abuse the Scriptures [20]. Religious concepts are not syncretised to one place or one era, they become fluid and traverse different boundaries [20]. If the notion of decapitation becomes a fluid concept (as it has) that Muslims across the world can fill with other sorts of grievances that legitimise their action, it is not difficult to understand how southern insurgents have adopted the practice of beheading.

Thus, not only do the Patani insurgents draw their inspiration from the historical continuities of the practice of beheading within Thai and Muslim histories but they also tap into neo/jihadist symbolic and semantic rhetoric.

The separatist insurgency's use of extreme violence and more particularly the practice of beheading appears to be effective as Thai Buddhists choose to desert their villages rather than having to face separatist violence, allowing the insurgency to reclaim control over sacred ancestral geographical spaces. Nonetheless, although, a majority of Thai Buddhists has fled the region, the insurgents' terror campaign has also sparked strong feelings of nationalism among those Buddhists who have chosen to stay and protect their homeland, generating a significant increase in small arms proliferation in the region under the benevolent eye of the Thai state [21]. Where recapture of the land for some equates with independence, it is a synonym for the loss of territory and ultimately of sovereignty for others. In fact, the southern politics of fear is a process largely bounded by a conventional notion of territory in which terror reigns, transforming and reconfiguring the geosocial spaces of southern Thailand and subsequently enforcing political change.

While Thai Buddhists describe decapitations as "hotrai" or atrocious, beheadings are used above all for their high emotional intensity impact on its audiences. In the context of southern Thailand, decapitation and other forms of extreme violence are used primarily to frighten the Thai Buddhist community, ultimately seeking to push them to leave the region while at the same time inspiring the Melayu Muslims either to join the struggle or stop collaborating with the enemy.

In failing to do so, Melayu Muslims are likely to be branded munafiq and in most cases will be punished, often by death. In some cases, the insurgents have threatened to cut off the ears of fellow Muslims who would disregard their warnings [22]. Threats of mutilation or beheading illustrate the way the insurgency uses fear of imminent physical harm or death to keep the Melayu community in line and their religious counterparts in disarray. In 2006, after 19-year-old Salahudin Toja was shot dead, his face was hacked beyond recognition [23]. The following year, in 2007, a 58-year-old Muslim assistant headman was killed, then after his attackers failed to decapitate him, he was crucified on two crossed planks and left to be found on a side road ([24,25]). In 2009, a young Melayu Muslim was found with his head and arms severed.

When observing the casualty data on Southern Thailand, the transformative process of the struggle into a cosmic war becomes particularly evident. Statistics reveal that insurgent violence (and beheadings) target mainly the civilian population followed by civil servants and security personnel. The primary victims of insurgent beheadings are Thai Buddhist civilians. 
When examining more closely the professional activities of beheading and general separatist violence victims in southern Thailand, a similar pattern can be found between the base and extreme types of violence. The victims' professions are particularly informative on the insurgency's re-identification process of the enemy. The insurgents not only have identified the state representatives and the Thai Buddhist civilian population as the kafir enemy that has to be crushed, but also any Melayu Muslim who would be in a line of work that can be affiliated with the state.

Ultimately, the insurgent use of beheadings and other types of extreme violence in Southern Thailand, although an outgrowth of the movement's transformation of the struggle into a cosmic war, can be interpreted as psychological operations in guerrilla warfare. The Patani practice of decapitation falls within a psychological strategy of "terrorism spectacle" which targets "the population, all population, one's troops, the enemy troops and the civilian population" [26] in order to win its audience's minds and hearts.

In Iraq, the beheadings of westerners are spectacle images destined to punish, humiliate and terrify a Western audience ([27], p. 30; [28]). In Southern Thailand, although the beheadings of kafir and munafiq present similar cognitive functions, they are, unlike the Iraqi experience, specifically targeted towards a much smaller immediate localised collective audience-i.e., the Thai Buddhists and Melayu Muslim communities inhabiting the three southern border provinces of Thailand. Because their target audience is not the international community but a smaller pool of witnesses, Patani insurgents have not or rarely advertised their acts of beheading in the media. When these have eventually found their way onto the Internet, it was aimed at enhancing the Patani insurgents' profile amongst (neo)jihadist circles and legitimising their claims to a defensive jihad. A possible explanation for the different situations in the two countries may lay in the divergence of registry within each insurgency's neojihadist discourse. Despite the glocalisation of neojihadism in Southern Thailand, the Patani struggle remains a localised conflict and the direct target audience of insurgent violence is the local community. The movement's ultimate preoccupation remains the creation of an independent Patani Darussalam rather than the re-establishment of a caliphate. Unlike in Iraq, the anti-western dimension is absent from the Patani neojihadist locus. However, although anti-western sentiments are not explicitly apparent they are not rejected either, they simply are not instrumentalised within the Patani rhetoric. Iraqi beheadings and Patani decapitations respectively target different audiences, diffuse different messages and seek a different type of publicity. Patani decapitations seek a more immediate impact on the ground. On this, the insurgents are clear: "Our fighters behead these victims because they want to spread fear and reach independence [of the Patani state] quickly" [29].

Therefore, it can be reasonably argued that the movement adopted the practice of beheading in their leading of a new campaign of terror for strategic purposes. In fact, it has been "knocked off" from the neojihadist arsenal of fear and terror tactics for its (perceived) propensity to trigger political change but also revived both a local historical tradition, which distinctively differentiates it from the Middle Eastern experiences. Hence, as the southern separatist insurgency progressively positions itself within the periphery of neojihadism, it is therefore not surprising that the insurgents have also adopted the use of extreme violence in addition to the jihadist rhetoric in the conduct of its struggle.

Finally, while insurgent beheadings are at the same time strategically causing the Thai Buddhists to flee their homes and hardening their attitudes towards the Melayu Muslims, it is also alienating the Patani community and its religious leaders who cannot condone the use of decapitation in the three 
southern border provinces. This begs the question of whether the separatist insurgency's use of beheading as a method of execution, although relatively "successful" so far, will not become in the long term counter-productive, as it was for Al Qaeda in Iraq which perceived the Iraqi beheadings as potentially damaging the organisation's cause by alienating Muslims ([14], p. 607; [30], p. 317). The absence of reported beheadings after June 2009 suggests that the community's disapproval of the practice may have gained the upper hand pushing the militants to abandon their use of this type of extreme violence in the conduct of their struggle.

\section{Conclusions}

In their transformation of an almost century old struggle into a cosmic war against the Thai state, the separatist terrorist insurgent movement in Southern Thailand adopted and glocalised a new locus of resistance located within the neojihadist sphere, propelling the struggle to unprecedented levels of violence. Not only have the insurgents knocked off some of their ideological ground from neojihadist radicalism but also some of its most extreme violent praxis, morphing in effect the southern conflict into a glocalised jihad.

In a sense, neojihadism has become the culture of reference from which violent Muslim radical groups can pick and choose elements that will be transferred and adapted to their needs. However, the process of praxio-theolo-ideological transference is not a straightforward one and is heavily influenced if not conditioned by the host culture, particularly in the different forms these consecutive specific violent manifestations will take. Therefore, to understand the specific forms in which transferred violence(s) will manifest itself in a particular culture, it is necessary to consider not only the global culture of reference but also the subculture(s) of reference within the host culture. As such, the specific form of manifestation of contemporary Patani beheadings can be better understood within the cultures of reference of the host culture.

The insurgency's adoption of extreme violence, in particular beheadings, results from the process of praxio-theolo-ideological transference of neojihadism and these new forms of violence are radically transforming the nature of Patani terrorism. While the perception that neojihadism and its violent praxis may be an adaptable blueprint to any Muslim identity conflict, the shapes, forms and significance that a violent glocalised jihad may take will depend on the local cultures of reference and the insurgent movement's ultimate pursued goal itself, i.e., an independent Patani Darussalam, which demonstrates how the current movement is shaped by a convergence of global and local forces under the impulse of globality. While global neojihadism impacts on the movement's mechanism of transference, the local Patani culture of reference continues to shape the struggle, while at the same time giving birth to a mediated glocalised jihad.

\section{Conflicts of Interest}

The author declares no conflict of interest. 


\section{References and Notes}

1. Andries Teeuw, and David Wyatt. Hikayat Patani. The Story of Patani. The Hague: Martinus Nijhoff, 1970.

2. Sukree Ibrahim. History of the Malay Kingdom of Patani. Athens: Ohio University, Center for International Studies, 1985.

3. Daniel Perret, Srisuchat Ammara, and Thanasuk Sombun. Études sur l'Histoire du Sultanat de Patani. Paris: École française d'Extrême-Orient, 2004.

4. Virginie Andre. "Southern Thailand: A Cosmic War?" In Radicalisation Crossing Borders: New Directions in Islamist and Jihadist Political, Intellectual and Theological Thought and Practice. Edited by Sayed Khatab, Muhammad Bakashmar and Ela Ogru. Melbourne: Global Terrorism Research Centre, Monash University, 2009, pp. 169-89.

5. Virginie Andre. "Globalization: A New Driving Force in Southern Thailand". In Terrorism and Social Exclusion: Misplaced Risk-Common Security. Edited by David Wright-Neville and Anna Halafoff. Cheltenham: Edward Elgar Publishing, 2010, pp. 116-35.

6. Virginie Andre. "From Colonialist to Infidel: Framing the Enemy in Southern Thailand's 'Cosmic War.'” In Culture, Religion and Conflict in Muslim Southeast Asia: Negotiation Tense Pluralisms. Edited by Joseph Camilleri and Sven Schottmann. Oxon: Routledge, 2012, pp. 109-25.

7. Human Rights Watch. No One is Safe. Insurgent Attacks on Civilians in Thailand's Southern Border Provinces. Bangkok: Human Rights Watch, 2007.

8. Mark Juergensmeyer. Terror in the Mind of God: The Global Rise of Religious Violence. Berkeley: University of California Press, 2003.

9. Pete Lentini. "The Transference of Neojihadism: Towards a Process Theory of Transnational Radicalisation." In Radicalisation Crossing Borders: New Directions in Islamist and Jihadist Political, Intellectual and Theological Thought and Practice. Edited by Sayed Khatab, Muhammad Bakashmar and Ela Ogru. Melbourne: Global Terrorism Research Centre, Monash University, 2009, pp. 1-32.

10. Virginie Andre, and Ela Orgu. Mapping Violence in Southern Thailand. Melbourne: Global Terrorism Research Centre, Monash University, 2011.

11. Virginie Andre. "Neojihadism and YouTube: Patani Militant Propaganda Dissemination and Radicalization." Asian Security 8 (2012): 27-53.

12. Virginie Andre. "The Janus Face of New Media Propaganda: The Case of Patani Neojihadist YouTube Warfare and Its Islamophobic Effect on Cyber-Actors." Islam and Christian-Muslim Relations 25 (2014): 335-56.

13. Pete Lentini. "Antipodal Terrorists? Accounting for Differences in Australian and Global Neojihadists." In The Globalization and Political Violence: Globalization's Shadow. Edited by Richard Devetak and Christopher Hugues. London: Routledge, 2008, pp. 181-202.

14. Lisa Campbell. "The Use of Beheadings by Fundamentalist Islam." Global Crime 7 (2006): 583-614.

15. Interview by Virginie Andre with former military general, Bangkok 2008.

16. Arjun Appadurai. "Dead Certainty: Ethnic Violence in the Era of Globalization." Public Culture 10 (1998): 225-47. 
17. Heinrich Schäfer. "The Janus Face of Religion: On the Religions Factor in 'New Wars." Numen 51 (2004): 407-37.

18. David Camroux, and Don Pathan. "Borders of/on the Mind, Borders in the Jungle: Islamic Insurgency and Ethno-Religious Irredentism in Southern Thailand". In Promoting Conflict or Peace through Identity. Edited by Nikki Slocum-Bradley. Aldershot: Ashgate Publishing, 2008, pp. 82-102.

19. Consuelo Corradi. "Identity and Extreme Violence-Some Elements for a Definition of Violence in Modernity." In Issues and Trends in Italian Sociology. Edited by Alessandro Cavalli. Naples: Scriptaweb, 2007, pp. 85-110.

20. BBC RADIO 4. "Islam and the Sword.” BBC Podcast, 2 October 2006.

21. On arms proliferation in Southern Thailand, please kindly refer to Diana Sarosi, and Janjira Sombutpoonsiri. Rule by the Gun: Armed Civilians and Firearms Proliferation in Southern Thailand. Bangkok: Nonviolence International Southeast, 2009.

22. Separatist leaflet. "From violent incidents occurring presently which build confusion and unrest from the news received." Undated.

23. "Four More Killed in Shootings in South." The Nation, 17 October 2006.

24. "Muslim Crucified, Two Buddhists Beheaded in Thailand: Police." Agence France Press, 28 November 2007.

25. "The Necessity of Moderation." Bangkok Post, 4 December 2007.

26. Tayacan. Psychological Operations in Guerrilla Warfare. Washington: Congressional Research Service, Library of Congress, 1984.

27. Jean-Claude Burger. “Journalisme Télévisuel.” In La Révolution Internet. Edited by Antoine Char and Roch Côté. Quebec: Presses Universitaires du Quebec, 2009, pp. 21-32.

28. Victoria Fontan. Voices from Post-Saddam Iraq: Living With Terrorism, Insurgency, and New Forms of Tyranny. Westport: Praeger Security International, 2008.

29. Marc Askew. “A Tale of Two Insurgents.” Bangkok Post, 19 July 2009.

30. Pete Lentini, and Muhammad Bakashmar. "Jihadist Beheading: A Convergence of Technology, Theology, and Teleology?" Studies in Conflict and Terrorism 30 (2007): 303-25.

(C) 2015 by the author; licensee MDPI, Basel, Switzerland. This article is an open access article distributed under the terms and conditions of the Creative Commons Attribution license (http://creativecommons.org/licenses/by/4.0/). 